\title{
Corporate Social Responsibility Demonstrated in Different Approaches to Corporate Extended Performance Reporting
}

\author{
Che Siqi ${ }^{1} \&$ Li Xuepei ${ }^{2}$ \\ ${ }^{1}$ College of Continuing Studies, Guangdong University of Foreign Studies, Guangzhou, China \\ ${ }^{2}$ Electronic Banking Center (Guangzhou), Industrial and Commercial Bank of China, China \\ Correspondence: Che Siqi, College of Continuing Studies, Guangdong University of Foreign Studies, \\ Guangzhou, China. E-mail: tshtt@sina.com
}

\author{
Received: May 5, 2015 Accepted: June 15, 2015 Online Published: August 18, 2015 \\ doi:10.5539/ass.v11n24p185 \\ URL: http://dx.doi.org/10.5539/ass.v11n24p185
}

\begin{abstract}
Corporate social responsibility is becoming a very popular tool for companies in outlining their own strategies (Stancu, Grigore, \& Rosca, 2011). Different approaches have been developed to perform corporate social responsibility due to increased market competition. The purpose of this essay is to analyze the importance of carrying out corporate responsibility by demonstrating three different approaches: value creation, risk management, and corporate philanthropy. This will include a particular focus on the advantages and disadvantages of these approaches to extended performance reporting, followed by recommendations and suggestions with an emphasis on the importance of corporate social responsibility. Finally, with detailed analysis, it will be demonstrated that there is not a perfect approach which can meet all the requirements from companies. The approaches to Corporate Extended Performance Reporting for realizing corporate social responsibility still lack sophistication and maturity.
\end{abstract}

Keywords: social responsibility, approach, performance reporting

\section{Introduction}

In the contemporary society, corporate social responsibility (CSR) investments were undertaken by a great number of corporations, especially by large multinational firms, which means that corporate social responsibility becomes more relevant to the development of world-wide corporations. It is gradually becoming a financial measure indicator for business success in the long run. In addition, it is generally perceived that corporate activities have a large impact on our environment, society and all stakeholders. Corporations, as one type of stakeholders, should pay attention not only to the short-term corporate interests, but also to the sustainable profits over a long period of time. For the sake of measuring and evaluating corporate social responsibility activities, accountability principles serve as standards and frameworks for corporate sustainable development. Especially, the development of accountability has come to be applied in sustainability reporting (Aras \& Crowther, 2009). Presently, Intensified corporate social responsibility has gradually become a contemporary mechanism in the modern business era (Gholami, 2011). It is evident that globalization has called for companies to help resolve social dilemmas and expanded the responsibilities of corporations (Hillman \& Keim, 2001). According to Friedman, R. and Friedman M., corporate responsibility should mainly focus on corporation profits (Friedman, 2009). This view, obviously, constrains corporate responsibility to purely company returns. However, the diversity of corporation types indicates that "a one-size-fits-all approach" cannot meet the overall rising needs (Schwartz \& Carroll, 2003). In this essay, the author introduces three common techniques: value creation, risk management and philanthropy to demonstrate various perspectives of corporate responsibility and their positive influence on sustainable development and accountabilities as well as their disadvantages and limitations in the aspects of extended performance reporting and reporting practice. In the following, three main approaches will be analyzed separately.

\section{Value Creation Approach}

According to Gholami (2011), corporate social responsibility is evidently a good way to create shared value, which is to successfully interconnect business success with social problems. The first main approach to link business success with social problems is value creation approach, which means that a sustainable business model 
can effectively resolve social problems. More exactly, the purpose of the value creation approach is to build a sustainable business model through innovation to drive future social development. In practice, the value creation approach bears a fundamental impact on the effective operation of corporate social responsibility (Debby et al., 2014). Sustainability reporting is the best case in demonstrating the value creation approach (Cook, 2008). Particularly, sustainability reporting takes multiple stakeholder interests into consideration, such as government departments, suppliers, employees, customers and communities. Employees, as one of the essential stakeholders, their satisfaction and business success are interdependent (Cook, 2008).

British Petroleum (BP) is a good example for explaining employees' satisfaction and its related economic success, as the oil spill in Gulf of Mexico tarnished BP's reputation and triggered an employment crisis. At the most difficult time, economic loss and the oil spill accident led to staff reduction, victims' compensation and long-term environmental restoration. Hence, managing employee relationships with BP Global Corporation, especially deceased staff, is a great challenge (Griggs, 2011). Secondly, reasonable compensation of approximately $\$ 400$ million has been paid for deceased employees and affected communities, who have suffered economic losses owing to the oil spill. Finally, BP devotes long term support to environmental restoration and the economic well-being of the Gulf region, which enhance employees' confidence in BP Global as well as joint efforts to improve sustainable and economic development for BP (Griggs, 2011).

\subsection{Advantages of Value Creation Approach to Extended Performance Reporting}

The value creation approach is a win-win strategy both for companies and society. Firstly, value creation approach linking with corporate social responsibility can assist corporations in improving energy efficiencies and save operational costs (Gholami, 2011). For instance, Wal-Mart organized staff training for training programs on sustainability (McElhaney, 2009). After Wal-Mart employees received sustainability-related training, one Wal-Mart staff proposed the removal of all vending machine light-bulbs, which can significantly conserve energy and reduce operational costs (McElhaney, 2009). This would report Wal-Mart as a good energy saver for the whole society, which will absolutely increase Wal-Mart's social awareness. Secondly, in order to display corporate social responsibility, corporations need to increase company accountability to enhance reputation among employees, suppliers and investors, which is also a favorable way to attract more investors, increase company confidentiality, stimulate their technological innovation, ensure the loyalty of talented employees to corporations, bring a great number of investment opportunities and intensify contradictions between competitors (McElhaney, 2009). A vivid example is from Johnson \& Johnson Company (Goetzel et al., 2002). Johnson \& Johnson Company saved approximately $\$ 250$ million in investing in employee health care programs (Goetzel et al., 2002). This would report Johnson \& Johnson as a high sense of responsibility for employees, which can not only enhance corporate image but also arouse the enthusiasm of employees. However, what is undeniable is that there also have limitations for value creation approach.

\subsection{Disadvantages of Value Creation Approach in Reporting Practice}

The first major problem of value creation approach associated with corporate social responsibility in reporting practice is how to measure its potential and actual financial benefits. The impact is that this may decrease credibility for companies' report as there is no unified criterion for reporting. Secondly, corporations still regard economic benefits as a tool for carrying out corporate social responsibility (Daum, 2003). Thirdly, the value creation approach should work in conjunction with the company's main competency, which means company social responsibility action should also consider the company's own operational strategy. A typical example would be Ford Motor Company, a world-famous automaker company (Hughes-Cromwick, 2011). In order to display Ford Motor Company's corporate responsibility, Ford decided to join in the breast cancer program. As an international automobile manufacturer, there is no strategic connection between breast cancer research and car manufacturing (McElhaney, 2009). This would report Ford Motor Company has health concern, but it has little impact on promoting cars sales. Finally, a number of value creation approaches only pays attention to main stakeholders, especially customers and shareholders, without taking employees and government bodies into consideration (Wang \& Juslin, 2013). This would impact employees' enthusiasm and satisfaction. Therefore, value creation approach should take multi-stakeholders' interests into consideration for achieving effective corporate responsibility.

\subsection{Recommendation}

Corporate responsibility primarily centres on business economic benefits and calls upon companies to perform under various rules and guidelines (Friedman, 2009) but corporate social responsibility can enhance the reputation of corporations (McElhaney, 2009). The value creation approach associated with corporate social responsibility may allow corporations and society achieve mutual benefits: in one way, the value creation 
approach can save operational and energy costs and simultaneously push society to efficiently utilize natural resources (Gholami, 2011); in the other way, the value creation approach incorporated into business strategies can promote the sustainable development of corporations. Therefore, business strategies and sustainable strategies coalesce, they can stimulate social development in the long run (McElhaney, 2009). Up to now, the value creation approach still has various limitations, such as incomplete frameworks, profit measurements, core competency connection, it is a fundamental approach to realizing corporate responsibility nonetheless (Debby et al., 2014).

\section{Risk Management Approach}

The second approach is risk management approach. It is obvious that managing risk is an important component in corporate social responsibility (Kytle \& Ruggie, 2005). Since a great number of companies fell bankrupt in recent years, much attention is paid to enhance the risk management ability of corporations (Wong, 2003). A company's reputation takes years to establish, but a scandalous incident can instantaneously bring it into ruin. Furthermore, it also requires decades to dispel negative images of a company. Thus, the most significant solution is to manage potential risks and integrate corporate social responsibility into companies' business strategies (Wong, 2003). Richemont Company does a perfect job in the risk management process (Audebrand \& Iacobus, 2008). Richemont quantified all identified risks into different levels according to influence, probability and occurrence. Moreover, according to each level of danger, Richemont set up different safe plans to extricate oneself from it (Audebrand \& Iacobus, 2008). In addition, the purpose of the risk management approach is compliance (Christie, 2009). To illustrate, Klynveld Peat Marwick Goerdeler (KPMG) adopts fair trade coffee practices by facilitating equal trade globally (Len \& Heaton, 2006). The main aim for fair trade is primarily to help developing countries achieve better economic conditions. Urging developed countries to import coffee, tea, bananas, cotton and cocoa at higher prices will undoubtedly be of assistance (Christie, 2009). In general, there are two types of risks associated with corporate social responsibility. The first is operational risks, which include compromises with rules and regulations, employee loyalty, and some specific operational risks. For instance, BP Global Company was embroiled in an oil spill in 2010 (Griggs, 2011). This accident is a big operational challenge for BP Company. The second risk may be in the production line, which involves harmful gases or raw materials pollution. Production risks may cause serious health problems or food safety issues. A prominent example is Japan's nuclear industry in 2011 (Kingston, 2012). On March 11 2011, the nuclear power plant explosion triggered by an earthquake released hazardous gas and radiation, which significantly impinged on public health and food safety (Wang \& Qian, 2011). Emergency steps in response to this incident showed corporate responsibility. Tokyo Electric Power Company failed to uphold safety guidelines and falsified documents in order to reduce hefty maintenance costs, which undoubtedly tainted Tokyo Electric Power Company's reputation (Suto et al., 2013). This incident shows the importance of establishing corporate social responsibility, as Tokyo Electric Power Company, which did not take this matter seriously by ignoring public safety concerns, suffered drastic losses as a consequence. Moreover, this incident also revealed the drawbacks of Tokyo Electric Power Company's risk management ability. In fact, Tokyo Electric Power Company was already aware of the potential likelihood of an accident, but declined to take serious preventive action (Suto et al., 2013).

\subsection{Advantages of Risk Management Approach to Extended Performance Reporting}

Firstly, the risk management approach can decrease operational risks for corporations, particularly by enhancing employees' satisfaction and cultivating an excellent atmosphere (Cook, 2008). In addition, employee involvement is a beneficial way to supervise company behaviour and preclude abusive human rights and personal scandals (Cook, 2008). This would impact the reporting by enhancing employee satisfaction. Secondly, the risk management approach can improve corporate reputation and enhance employee loyalty (Len \& Heaton, 2006). Tokyo Electric Power Company suffered significant economic losses due to its neglect in managing risks thoroughly (Suto et al., 2013). Tokyo Electric Power Company now faces billions of dollars in damages as well as an irremediably tarnished image. This would impact the reporting of Tokyo Electric Power Company's image and reputation. Though the risk management approach has some advantages for extended performance reporting, we can not neglect its limitations, which will be talked below.

\subsection{Disadvantages of Risk Management Approach in Reporting Practice}

Firstly, for small and medium enterprises, social responsibility fees are costly, so small and medium companies in Europe believe that corporate social responsibility is a financial burden (Perrini \& Morsing, 2009). This would impact the reporting accuracy. Secondly, economic capabilities, human capital, management experience and time are major constraints for the sustainable development of small and medium enterprises (Hart, 2012). This would also impact the accuracy and reliability of reporting. Thirdly, for mergers and acquisitions, some multinational 
companies establish platforms without understanding local cultural-specific situations, which may also be a potential risk for their future sustainable development. For instance, Telenor Group expands its market to Bangladesh via acquisitions (Falkenberg \& Falkenberg, 2009). However, this has proved to be a complicated undertaking for Telenor Group as both countries embody different cultures, languages and laws, making it difficult for Telenor Group to gauge the overall environment and discern cultural discrepancies (Falkenberg \& Falkenberg, 2009). This would generate a bad influence on Telenor Group's reporting performance.

\subsection{Recommendation}

In brief, risk management approach has a significant impact on corporate social responsibility (Wong, 2003). Benefits of the risk management approach lie in the reduction of operational risks, rising of employee satisfaction and enhancement of company reputation and social responsibility. If companies manage potential risks in advance, the likelihood of disaster will be considerably curtailed. However, cost is a major problem puzzling Tokyo Electric Power Company and other small and medium enterprises. The risk management approach needs time, human capital and experienced experts, which small and medium companies cannot afford. With the aim of nurturing a sustainable environment and harmonious society, small and medium companies should cluster together through joint efforts to overcome money shortages. All in all, risk management approach plays a substantial role in company operation; solutions should be settled earlier to escape potential risks.

\section{Corporate Philanthropy Approach}

The third approach is corporate philanthropy approach, which means that companies donate money to communities and non-profit organizations (Fioravante, 2010). During this process, donating companies aid non-profit organizations and communities without receiving any benefit in return. Generally, the corporate philanthropy approach embodies two targets. The first is non-profit organizations; the second is communities (Wang \& Qian, 2011). Community-based development is a popular plan that some corporations prefer (Fioravante, 2010). Thickening interrelationships between local communities and companies enhance local sustainable development. Furthermore, it is believed that small and medium enterprises (SMEs) are unable to donate millions of dollars and a large number of products, as to their limited resources and finite employees. Actually, SMEs, however, can approach corporate social responsibility as well by encouraging employees to donate goods, time and office space to charities. Through encouraging process, it provides an opportunity for companies to employ quality employees, reinvest in local communities and attract new customers. A good example is that the MDVIP Foundation created Thanksgiving baskets for needed families, which is a tremendous asset for needy families and a good way to show corporate social responsibility and improve MDVIP Foundation's reputation and influence (Whitaker, 2008). The purpose of corporate philanthropy approach is to provide skills and monetary donations to help those in need (Fioravante, 2010). The impact of corporate philanthropy is less significant compared with the value creation and risk management approaches (Wang \& Qian, 2011). In the short term, the philanthropy-based approach can increase company publicity, analogous to an advertisement, but requires consistency if it is to be employed over the long-term. The dilemma is something no one can avoid. Properly handled, however, the problem can also bring some benefits.

\subsection{Advantages of Corporate Philanthropy Approach to Extended Performance Reporting}

In fact, the philanthropy-based approach is a win-win policy. Firstly, the corporate philanthropy approach is essentially altruistic, which means corporations contribute to local community activities. Conversely, local community activities are a good advertisement for improving companies' reputation. Most importantly, corporate philanthropy opportunities may even create a new marketplace, stimulating consumption and increasing sales in rural areas. Particularly, corporate philanthropy is closely connected with company brands, which can produce an effective and efficient advertisement. To illustrate, Fujitsu Company adopted the corporate social responsibility approach by supporting the construction of public infrastructure through technology innovation (Crainer \& Dearlove, 2010). Fujitsu Company established Fujitsu Way to respond vigilantly to social issues and assume more responsibility for society's sustainable development. Fujitsu Way provides a direction for Fujitsu Company and uses Fujitsu's own technological innovation to deliver global solutions (Hart, 2012). What is also with noticing is that corporate philanthropy approach has some drawbacks as below.

\subsection{Disadvantages of Corporate Philanthropy Approach in Reporting Practice}

Firstly, short-term sponsorship is not sustainable. Donated companies still seek economic rewards for their contributions. If companies cannot consistently provide monetary donations to communities or non-profit organizations, their strategies cannot be fulfilled in the long run. Eventually, short-term company donations will be of minimal use for charities and may even result in minor social revolution. The impact for this reporting is not consistent. Secondly, there is no regulatory mechanism to supervise how charities spend money. What is 
meant by this is that non-profit organizations' reports may be falsified, which can substantially decrease confidentiality between donors and charities on reporting.

\subsection{Recommendations}

In summary, corporate philanthropy is an approach which not only reflects the corporate social responsibility of companies, but also brings them significant short-term financial benefits (Fioravante, 2010). However, donation processing lacks supervision, which may lead to forging of reports. Therefore, efforts should be devoted to administering the processing of donations. Besides, government should take pragmatic measures through incentives and rewards for support. Overall, the philanthropy-based approach should be developed as a sustainable one in the long run. Governments should also pay attention to supporting corporate social responsibility performance.

\section{Conclusion}

In practice, with the increasing influence of corporate social responsibility, there have been a great number of perspectives on defining corporate responsibility (Boeger, Murray \& Villiers, 2008). However, how to convey corporate social responsibility is still a controversial question. In this essay, three common approaches to corporate extended performance reporting have been introduced to demonstrate corporate social responsibility. Through introducing the purposes, impacts and specific characteristics of the three approaches and analyzing their benefits and limitations in the aspects of extended performance reporting and reporting practice, it can be concluded that each company selects slightly different approaches to display corporate social responsibility and there is no absolutely correct approach to demonstrate corporate social responsibility because there is no ideal one-size-fits-all approach for corporations. Efforts should be made on improving the efficiency of each one. In fact, the main consideration for companies in implementing corporate social responsibility still revolves around economic benefits (Crowther \& Rayman-Bacchus, 2004). Corporate responsibility and financial profits are interdependent. In the long run, corporate social responsibility will acquire increasing importance and priority. Hence, more concerns should be focused on making suggestions to improve company performance reporting in order to realize potential economic benefits in the future.

\section{References}

Aras, G., \& Crowther, D. (2009). Corporate sustainability reporting: A study indisingenuity? Journal of Business Ethics, 87, 279-288. http://dx.doi.org/10.1007/s10551-008-9806-0

Audebrand, L. K., \& Iacobus, A. (2008). Avoiding potential traps in fair trade marketing: A social representation perspective. Journal of Strategic Marketing, 16(1), 3. Retrieved from http://search.proquest.com/docview/ 862643410 ?accountid $=11232$

Boeger, N., Murray, R., \& Villiers, C. (Eds.). (2008). Perspectives on Corporate Social Responsibility. Edward Elgar Publishing.

Christie, R. S. (2009). Corporate social responsibility \& SH\&E regulatory compliance. Professional Safety, 54(12), 20-21. Retrieved from http://search.proquest.com/docview/200402617?accountid=11232

Cook, S. (2008). The essential guide to employee engagement; better business performance through staff satisfaction. Reference and Research Book News, 23(4). Retrieved from http://search.proquest.com/ docview/199727892?accountid=11232

Crainer, S., \& Dearlove, D. (2010). Leading Change: Inside Fujitsu. Business Strategy Review, 21(4), 7-14. http://dx.doi.org/10.1111/j.1467-8616.2010.00696.x

Crowther, D., \& Rayman-Bacchus, L. (2004). Perspectives on corporate social responsibility. Reference and Research Book News, 19(3) Retrieved from http://search.proquest.com/docview/199619676?accountid $=11232$

Daum, J. H. (2003). Intangible assets and value creation. John Wiley \& Sons.

Debby, J. F., Mukhtaruddin, Yuniarti, E., Saputra, D., \& Abukosim. (2014). Good corporate governance, company's characteristics and firm's value: Empirical study of listed banking on indonesian stock exchange. GSTF Business Review (GBR), 3(4), 81-88. Retrieved from http://search.proquest.com/docview/16654 55822? accountid $=11232$

Falkenberg, A. W., \& Falkenberg, J. (2009). Ethics in international value chain networks: The case of telenor in bangladesh. Journal of Business Ethics, 90, 355-369. doi:http://dx.doi.org/10.1007/s10551-010-0429-x

Fioravante, P. L. (2010). Corporate philanthropy: A strategic marketing consideration. The Journal of Applied 
Business and Economics, 11(3), 91-96. Retrieved from http://search.proquest.com/docview/76754836 2? accountid $=11232$

Friedman, M. (2009). Capitalism and freedom. University of Chicago Press.

Gholami, S. (2011). Value creation model through corporate social responsibility (CSR). International Journal of Business and Management, 6(9), 148-154. Retrieved from http://search.proquest.com/docview/89006 0971? accountid $=11232$

Goetzel, R. Z., Ozminkowski, R. J., Bruno, J. A., \& Rutter, K. R. (2002). The long-term impact of johnson \& johnson's health \& wellness program on employee health risks. Journal of Occupational and Environmental Medicine, 44(5), 417-424. Retrieved from http://search.proquest.com/docview/212699234?accountid= 11232

Griggs, J. W. (2011). BP GULF OF MEXICO OIL SPILL. Energy Law Journal, 32(1), 57-79. Retrieved from http://search.proquest.com/docview/869071045?accountid=11232

Hahn, R. (2012). Standardizing social responsibility? new perspectives on guidance documents and management system standards for sustainable development. IEEE Transactions on Engineering Management, 59(4), 717. Retrieved from http://search.proquest.com/docview/1114785660?accountid=11232

Hart, S. C. (2012). Japan's nuclear crisis: The routes to responsibility. Choice, 50(2), 355-356. Retrieved from http://search.proquest.com/docview/1113329036?accountid=11232

Hillman, A. J., \& Keim, G. D. (2001). Shareholder value, stakeholder management, and social issues: What's the bottom line? Strategic Management Journal, 22(2), 125-139. Retrieved from $\mathrm{http}: / /$ search.proquest.com/docview/225008661?accountid=11232

Hughes-cromwick, E. (2011). Ford motor company's global electrification strategy. Business Economics, 46(3), 167-170. http://dx.doi.org/10.1057/be.2011.10

Kingston, J. (Ed.). (2012). Natural disaster and nuclear crisis in Japan: response and recovery after Japan's 3/11. Routledge.

Kytle, B., \& Ruggie, J. G. (2005). Corporate social responsibility as risk management: A model for multinationals.

Len, T. W., \& Heaton, S. (2006). Fair trade marketing: An exploration through qualitative research. Journal of Strategic Marketing, 14(4), 411-426. Retrieved from http://search.proquest.com/docview/197467509?accou ntid $=11232$

McElhaney, K. (2009). A strategic approach to corporate social responsibility. Leader to Leader, 52(1), 30-36.

Perrini, F., \& Morsing, M. (2009). CSR in SMEs: do SMEs matter for the CSR agenda? Business ethics, 18(1), 1-6. http://dx.doi.org/ 10.1111/j.1467-8608.2009.01544.x

Schwartz, M. S., \& Carroll, A. B. (2003). Corporate social responsibility: A three-domain approach. Business Ethics Quarterly, 13(4), 503-530. http://dx.doi.org/10.1017/S1052150X00006722

Stancu, A., Grigore, G. F., \& Rosca, M. (2011). Consumers' perceptions towards corporate social responsibility initiatives - a qualitative approach. Transformations in Business \& Economics, 10(2), 754. Retrieved from http://search.proquest.com/docview/929353320?accountid=11232

Suto, Y., Hirai, M., Akiyama, M., Kobashi, G., Itokawa, M., Akashi, M., \& Sugiura, N. (2013). Biodosimetry of restoration workers for the tokyo electric power company (TEPCO) fukushima daiichi nuclear power station accident. Health Physics, 105(4), 366. Retrieved from http://search.proquest.com/docview/1432856 955? accountid $=11232$

Wang, H., \& Qian, C. (2011). Corporate philanthropy and corporate financial performance: the roles of stakeholder response and political access. Academy of Management Journal, 54(6), 1159. Retrieved from http://search.proquest.com/docview/916166944?accountid=11232

Wang, L., \& Juslin, H. (2013). Corporate social responsibility in the chinese forest industry: Understanding multiple stakeholder perceptions. Corporate Social - Responsibility and Environmental Management, 20(3), 129. Retrieved from http://search.proquest.com/docview/1349553257?accountid=11232

Whitaker, K. (2008, March 5). Business bookshelf: Just don't call them rich. Wall Street Journal. Retrieved from $\mathrm{http}: / /$ search.proquest.com/docview/399024247?accountid=11232

Wong, K. M. (2003). Bankruptcy as a risk management tool: Economic and social implications. Review of 
Business, 24(3), 46-51. Retrieved from http://search.proquest.com/docview/220958881?accountid=11232

\section{Copyrights}

Copyright for this article is retained by the author(s), with first publication rights granted to the journal.

This is an open-access article distributed under the terms and conditions of the Creative Commons Attribution license (http://creativecommons.org/licenses/by/3.0/). 